Article

\title{
Anticancer Activity of Moringa peregrina (Forssk.) Fiori.: A Native Plant in Traditional Herbal Medicine of the United Arab Emirates
}

\author{
Salama Khamis Sultan Al Kaabi ${ }^{1}$, Annadurai Senthilkumar ${ }^{1}$, Jaleel Kizhakkayil ${ }^{2}$, \\ Mohammed Abdul Muhsen Alyafei ${ }^{1}$, Shyam Sreedhara Kurup ${ }^{1}$, Ayesha S. Al Dhaheri ${ }^{2, *(D)}$ and Abdul Jaleel ${ }^{1, *}$
}

check for

updates

Citation: Al Kaabi, S.K.S.;

Senthilkumar, A.; Kizhakkayil, J.;

Alyafei, M.A.M.; Kurup, S.S.; Al

Dhaheri, A.S.; Jaleel, A. Anticancer

Activity of Moringa peregrina (Forssk.)

Fiori.: A Native Plant in Traditional

Herbal Medicine of the United Arab

Emirates. Horticulturae 2022, 8, 37.

https://doi.org/10.3390/

horticulturae 8010037

Academic Editor: Riccardo Motti

Received: 5 November 2021

Accepted: 15 December 2021

Published: 30 December 2021

Publisher's Note: MDPI stays neutral with regard to jurisdictional claims in published maps and institutional affiliations.

Copyright: (c) 2021 by the authors. Licensee MDPI, Basel, Switzerland. This article is an open access article distributed under the terms and conditions of the Creative Commons Attribution (CC BY) license (https:// creativecommons.org/licenses/by/ $4.0 /)$.
1 Department of Integrative Agriculture, College of Agriculture and Veterinary Medicine, United Arab Emirates University, Al Ain P.O. Box 15551, United Arab Emirates; 201108708@uaeu.ac.ae (S.K.S.A.K.); senthilkumar_a@uaeu.ac.ae (A.S.); mohammed.s@uaeu.ac.ae (M.A.M.A.); skurup@uaeu.ac.ae (S.S.K.)

2 Department of Nutrition and Health, College of Medicine and Health Sciences, United Arab Emirates University, Al Ain P.O. Box 15551, United Arab Emirates; JaleelK@uaeu.ac.ae

* Correspondence: ayesha_aldhaheri@uaeu.ac.ae (A.S.A.D.); abdul.jaleel@uaeu.ac.ae (A.J.); Tel.: +971-3-713-4576 (A.S.A.D.)

\begin{abstract}
Moringa peregrina (Forssk.) Fiori. is a native desert tree growing in United Arab Emirates (UAE). The plant is being cultivated in many parts of UAE, owing to its uses in traditional medicinal and food systems. In the present study bioactivities of cultivated M. peregrina species samples are evaluated with cytotoxic studies in the human breast cancer cell line (MCF-7) and human colon adenocarcinoma cell line (Caco-2). Different extracts with hexane, chloroform, acetone and methanol were prepared from tubers, leaves and stem of M. peregrina for estimating their antioxidant contents and anticancer activities. The study was performed at different concentrations and all the extracts showed dose-depended response on both the cell lines. Among the extracts tested, the chloroform extract of stem showed remarkable anti-proliferative/cell death activity $\left(\mathrm{IC}_{50}=45.53 \mu \mathrm{g} / \mathrm{mL}\right.$ of $48 \mathrm{~h}$ incubation and $33.32 \mu \mathrm{g} / \mathrm{mL}$ of $72 \mathrm{~h}$ incubation) on MCF-7 cell lines. Whereas the same extract showed comparatively less activity $\left(\mathrm{IC}_{50}=93.75 \mu \mathrm{g} / \mathrm{mL}\right.$ of $48 \mathrm{~h}$ incubation and $87.76 \mu \mathrm{g} / \mathrm{mL}$ of $72 \mathrm{~h}$ incubation) on Caco-2 cell lines. The anti-proliferative effect of leaf extract with chloroform showed a drastic change in cell viability from 48 to $72 \mathrm{~h}$ incubation, in MCF-7 cells 220 to $87.5 \mu \mathrm{g} / \mathrm{mL}$ and in Caco-2 cells 500.9 to $72.9 \mu \mathrm{g} / \mathrm{mL}$, respectively. Moreover, less than $200 \mu \mathrm{g} / \mathrm{mL}$ of $\mathrm{IC}_{50}$ values reported in hexane extracts of tubers $(188.6 \mu \mathrm{g} / \mathrm{mL}$ for $48 \mathrm{~h}$ and $164.3 \mu \mathrm{g} / \mathrm{mL}$ for $72 \mathrm{~h})$, acetone extracts of tubers $(167.4 \mu \mathrm{g} / \mathrm{mL}$ for $72 \mathrm{~h})$ and acetone extracts of stem $(171.5 \mu \mathrm{g} / \mathrm{mL}$ for $48 \mathrm{~h}$ and $101.7 \mu \mathrm{g} / \mathrm{mL}$ for $72 \mathrm{~h}$ ) on MCF-7 cells. PARP (Poly (ADP-ribose) polymerase) cleavage assay and DNA fragmentation assay performed to understand the cause of cell death. Treatment of extract on the normal fibroblast cell line required more concentration for cytotoxicity compared to the treatment on the cancer cells. This ability of the extract proved the anti-cancer property of the M. peregrina extract from the stem, tuber and leaves. The information provided in the present study enables further studies on the isolation and characterization of an anticancer molecule from the tubers of M. peregrina.
\end{abstract}

Keywords: Moringa peregrina; natural products; cancer management; breast cancer; colon cancer

\section{Introduction}

Cancer is one of the serious causes of human mortality and the global cancer burden estimates 9.6 million deaths and 18.1 million new cases in 2018 [1,2]. The high incidence of cancer burdens is due to the use of tobacco products, unhealthy diet, pollution, lack of physical activity, etc. Among all other cancers, breast, colon and prostate cancer account for the highest incidents [3]. Nowadays, a number of treatment options have been 
adopted based on the location and stage of tumors such as radiotherapy, chemotherapy, surgery of tumor, immunotherapy, cancer vaccinations and stem cell transformation, etc. Chemotherapy is a very effective treatment option when used in combination with other therapies [4]. This option mainly targets the rapidly proliferating cancer cells by one or more cytotoxic drugs. Nevertheless, these drugs also affect the normal body cells (digestive tract, bone marrow and hair follicle cells) which are quickly proliferating under usual conditions [5]. These types of side effects warrant the necessity of back to nature approach in cancer management [6].

Herbal extracts containing naturally occurring small molecules have provided experimental evidence and are clinically significant in treatment strategies of cancer [6]. The literature indicates that medicinal plants are the promising source of new anticancer drugs as many natural derivatives and/or their analogs have already been approved for cancer therapy [7]. Moreover, extensive studies [8-13] are continuing for the development of new anticancer leads from a plant source that kills the cancer cells without affecting the non-target body cells. Crude extract from plant parts of the medicinally important species exhibit the anti-cancer potential and identified that bioactive compounds are responsible for that $[14,15]$. Curcumin from turmeric, catechin from tea, resveratrol from grapefruit, etc. identified from the crude extract and clinical trials for the cancer treatment are currently undergoing [16].

The plants in the Moringa genus have always attracted scientists due to their high medicinal activities. The earlier studies on the medicinal properties of the Moringa genus were mainly focused on M. oleifera [17-22], since the species is readily available and is being used in traditional medicinal systems and also in food preparations in Africa and Asia [23]. Moringa peregrina (Forssk.) Fiori. is mostly found in the desert as well as wadi and hill regions in Arabian Peninsula [24], as it is well-adapted to harsh climatic conditions [25]. This plant is deciduous tree growing up to $3-10 \mathrm{~m}$ height with a grayish green bark [26]. Recently, we summarized reports of traditional uses, pharmacological efficacy and phytochemistry of M. peregrina [27], and also evaluated the chemical composition and antioxidant potential of essential oil from its seeds [28]. This plant has a wide range of traditional medicinal uses and has been screened for various pharmacological activities [29-32]. In Arab countries, $M$. peregrina plant is being used in folk medicine because of this plant's ability to cure diseases like skin rashes [33], wound healing [34], diabetes [35,36], disinfectant [37] and also to treat fever, headache, constipation, back and muscle pains, slimness, burns and labor pain [38-40]. Anti-cancerous properties of extracts M. peregrina with various polar and non-polar solvents are not elucidated well.

One of the unique features of M. peregrina is the formation of root tuber in the seedling phase [26]. There are no major studies on the medicinal potential of these tubers. Various scattered studies about the extracts isolation by using the different parts of the M. peregrina are reported, however different polar and non-polar solvents such as chloroform, acetone, methanol and hexane on leaves, stem and tuber are novel in the present study. Also, there was no previous reports about the tuber and entire stem extracts isolation from the M. peregrina. Anti-cancer properties of its essential oils are reported earlier [41], but the research about the ability of different extracts from different parts of $M$. peregrina and their potential in managing cancers is scanty. Therefore, this investigation is aimed to study the anti-proliferative and apoptotic potential of various parts viz. leaves, stem and tubers of $M$. peregrina on MCF-7 and Caco-2 cells.

\section{Materials and Methods}

\subsection{Plant Material and Preparation of Crude Extracts}

The samples viz, leaves, stem and tubers were collected from Al Foah [24 $21^{\prime} 31.139^{\prime \prime} \mathrm{N}$ $55^{\circ} 47^{\prime} 57.239^{\prime \prime} \mathrm{E}$ (Altitude $303 \mathrm{M}$ )], Al Ain, UAE. The samples were initially washed with tap water then washed with $10 \%$ sodium hypochlorite to prevent contamination. Finally, the samples were rinsed thoroughly in distilled water. The samples were dried in shade followed by a oven $\left(50^{\circ} \mathrm{C}\right)$. Dried samples were powdered with an electric blender. The 
powdered samples $(500 \mathrm{~g}$ ) were used for extraction by Soxhlet apparatus with increasing polarities viz., hexane, chloroform, acetone and methanol. The extracts were combined and the solvent was evaporated and kept at $+4{ }^{\circ} \mathrm{C}$ and used for further study.

\subsection{Cell Culture and Cell Proliferation Assay}

Human breast cancer cell line (MCF-7), human colon adenocarcinoma cell line (Caco-2) and 3T3-L1 (undifferentiated fibroblast) were purchased from the European Collection of Animal Cell Cultures (Salisbury, Wilts., UK). Both types of cells were cultured in the Eagle's minimal essential medium supplemented with $10 \%$ heat-inactivated fetal bovine serum and $1 \%$ penicillin-streptomycin. The cultures were maintained at $37^{\circ} \mathrm{C}$ in a humidified atmosphere with $5 \% \mathrm{CO}_{2}$ in the incubator. All cell culture reagents were obtained from Invitrogen Ltd. (Grand Island, NY, USA). Cells were cultured in the tissue culture flask until attain $70 \%$ confluency. Cells seeded in 96-well culture plates at a density of $2 \times 10^{4}$ cells/well and incubated at $37^{\circ} \mathrm{C}$ for $24 \mathrm{~h}$. After incubation, cells were treated with different concentrations of the extracts viz. 1 to $1000 \mu \mathrm{g} / \mathrm{mL}$. The stock solution of extracts was prepared in dimethyl sulfoxide (DMSO) and stored at $-20{ }^{\circ} \mathrm{C}$ until use. Culture plates were incubated at $37^{\circ} \mathrm{C}$ in an incubator for 48 and $72 \mathrm{~h}$.

Cell viability was measured using the MTT (3-(4,5-dimethylthiazol-2-yl)-2,5diphenyltetrazolium bromide) (Sigma Aldrich, Saint Louis, MO, USA) colorimetric assay based on the standard method [42] and as described earlier [43]. The plates were incubated for a further $3 \mathrm{~h}$ at $37^{\circ} \mathrm{C}$. After the addition of $25 \mu \mathrm{L}(5 \mathrm{mg} / \mathrm{mL})$ of MTT reagent into each well, cells were incubated at $37^{\circ} \mathrm{C}$ for $4 \mathrm{~h}$. After incubation, the plates were centrifuged at $1500 \mathrm{rpm}$ for $5 \mathrm{~min}$ and the medium was removed from all the wells. The formazan crystals formed inside the well were then solubilized in $200 \mu \mathrm{L}$ of DMSO. Plates were gently shaken to dissolve the formazan crystals and absorbance taken at $570 \mathrm{~nm}$ wavelength in the microplate reader (Thermo Scientific Multiscan GO, Waltham, MA, USA). Cytotoxicity of the extracts was expressed as a percentage of the absorbance measured in control untreated cells [44].

\subsection{DNA Fragmentation Assay}

Cells were detached with phosphor buffer saline (PBS) and washed with fresh PBS as per the protocol [45]. A total of $100 \mu \mathrm{L}$ of dimethyl sulfoxide (DMSO) was added to the Eppendorf tube containing cell pellet and vortex and was mixed well. An equal volume $(100 \mathrm{~mL})$ of TE buffer ( $\mathrm{pH} 7.4)$ with $2 \%$ SDS was added, followed by mixing and vortexing. The sample was centrifuged at $12,000 \times g$ and supernatant was loaded into the agarose gel.

\subsection{PARP (Poly(ADP-ribulose) Polymerase) Cleavage Assay}

PathScan ${ }^{\circledR}$ Cleaved PARP (Asp214) Sandwich ELISA Kit (Cell Signalling Technology, Danvers, MA, USA) was used to detect the extent of PARP cleavage in the cancer cells with different concentrations of Moringa extracts treatment. Based on the cell viability results, for path scan analysis 500 and $1000 \mu \mathrm{g} / \mathrm{mL}$ of different solvents extracts concentration were used. Briefly, $0.1 \times 10^{6}$ cells were seeded on six-well plates, and the cells were maintained overnight in a $5 \% \mathrm{CO}_{2}$ incubator at $37^{\circ} \mathrm{C}$, before introducing culture medium with extract preferred concentrations. Following incubation for $72 \mathrm{~h}$, the cells were harvested, and cleaved PARP was measured following the manufacturer's protocol.

\subsection{Statistical Analysis}

The results of cell proliferation were calculated from the data obtained in three replicates and the values are expressed as mean $\pm \mathrm{SD}$. Statistical analysis was performed by graph pad prism 9.3 and the values at $p<0.05$ or less were considered as statistically significant. 


\section{Results and Discussion}

For the current study, leaves, stem and tubers of M. peregrina were extracted with polar solvents acetone, methanol and non-polar solvents like hexane and chloroform. The extract yield of $M$. peregrina prepared by various solvents (viz. hexane, chloroform, acetone and methanol) is summarized in Table 1 . Highest percentage of extract yield was obtained in the methanol extract (leaves-11.79\%; stem-13.0\%; tubers-5.62\%). Generally, the yield of solvent extraction of plant parts relies on the solvent polarity, method of extraction and the chemical properties of the phytochemicals [46]. The extract yield obtained in the present study suggests that the M. peregrina plant parts are rich in high polar molecules.

Table 1. Yield of hexane, chloroform, acetone and methanol extracts of M. peregrina.

\begin{tabular}{ccc}
\hline Plant Parts & Name of the Extract & Yield (\%) \\
\hline & Hexane & 0.63 \\
Tubers & Chloroform & 0.40 \\
& Acetone & 0.49 \\
& Methanol & 5.62 \\
\hline \multirow{2}{*}{ Leaves } & Hexane & 4.89 \\
& Chloroform & 5.36 \\
& Acetone & 1.43 \\
& Methanol & 11.79 \\
\hline \multirow{2}{*}{ Stem } & Hexane & 2.07 \\
& Chloroform & 0.48 \\
\end{tabular}

The results on anti-proliferative and apoptotic effect of various extracts of $M$. peregrina tubers, leaves and stem on MCF-7 and Caco-2 cell lines treated for 48 and $72 \mathrm{~h}$ are presented in the graphical Figures 1-3, respectively, and the $\mathrm{IC}_{50}$ values are given in Table 2. Doxorubicin was used as a positive control (Figure 4) to detect the effect on the MCF-7 and Caco-2. The anti-proliferative and cell death assay indicated that the inhibition cell growth of both the cell lines was in a concentration-dependent manner. In the present study, hexane extract of tubers, chloroform extract of leaves and chloroform extract of the stem induced the cell death of MCF-7 at the lowest concentrations. Among all the three plant parts used for the study, chloroform extracts of the stem on the MCF-7 showed lowest $\mathrm{IC}_{50}$ values, 45.53 and $33.32 \mu \mathrm{g} / \mathrm{mL}$ with 48 and $72 \mathrm{~h}$, respectively. The cell lines MCF-7 are more sensitive to the extract, especially chloroform extract of stem, than Caco-2 cells, after $72 \mathrm{~h}$ of cultivation. Cell death of MCF-7 with Moringa root extracts are previously reported and it showed the $\mathrm{IC}_{50}$ values with root core extracts are slightly higher than our result with stem extract and with outer core extracts of root was more than $100 \mu \mathrm{g} / \mathrm{mL}$ [15]. It indicates the chloroform stem extract isolated may contain more potent phytochemicals than the root extract. However, chloroform extract of tubers, hexane extract of leaves and methanol extract of stem induced the cell proliferation of MCF-7 even at the highest concentration tested, and the same trend was also observed in Caco- 2 cell lines. Some forms of extract exhibited a drastic dropdown in the viability in both MCF-7 and Caco-2 cells after $72 \mathrm{~h}$ of exposure compared to $48 \mathrm{~h}$. Acetone extracts of tubers required only $167.4 \mu \mathrm{g} / \mathrm{mL}$ of extract for $50 \%$ of the cell death at $72 \mathrm{~h}$ in the MCF-7 cells, whereas $48 \mathrm{~h}$ incubation required $807.8 \mu \mathrm{g} / \mathrm{mL}$ of extract. The same pattern of cell death was also observed in the methanol extracts of leaves in both cell lines. This may be due to the lowest rate of infiltration of the extract into the cells through the cell membrane at a short term of exposure. When exposure time increases, a longer chain of phytochemical may be able to infiltrate through the cell membrane and be able to prevent cell proliferation. 



- 48 hours



- 48 hours

72 hours



48 hours

72 hours

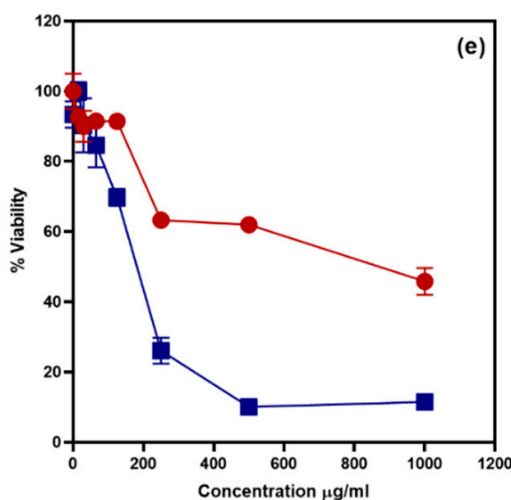

- 48 hours
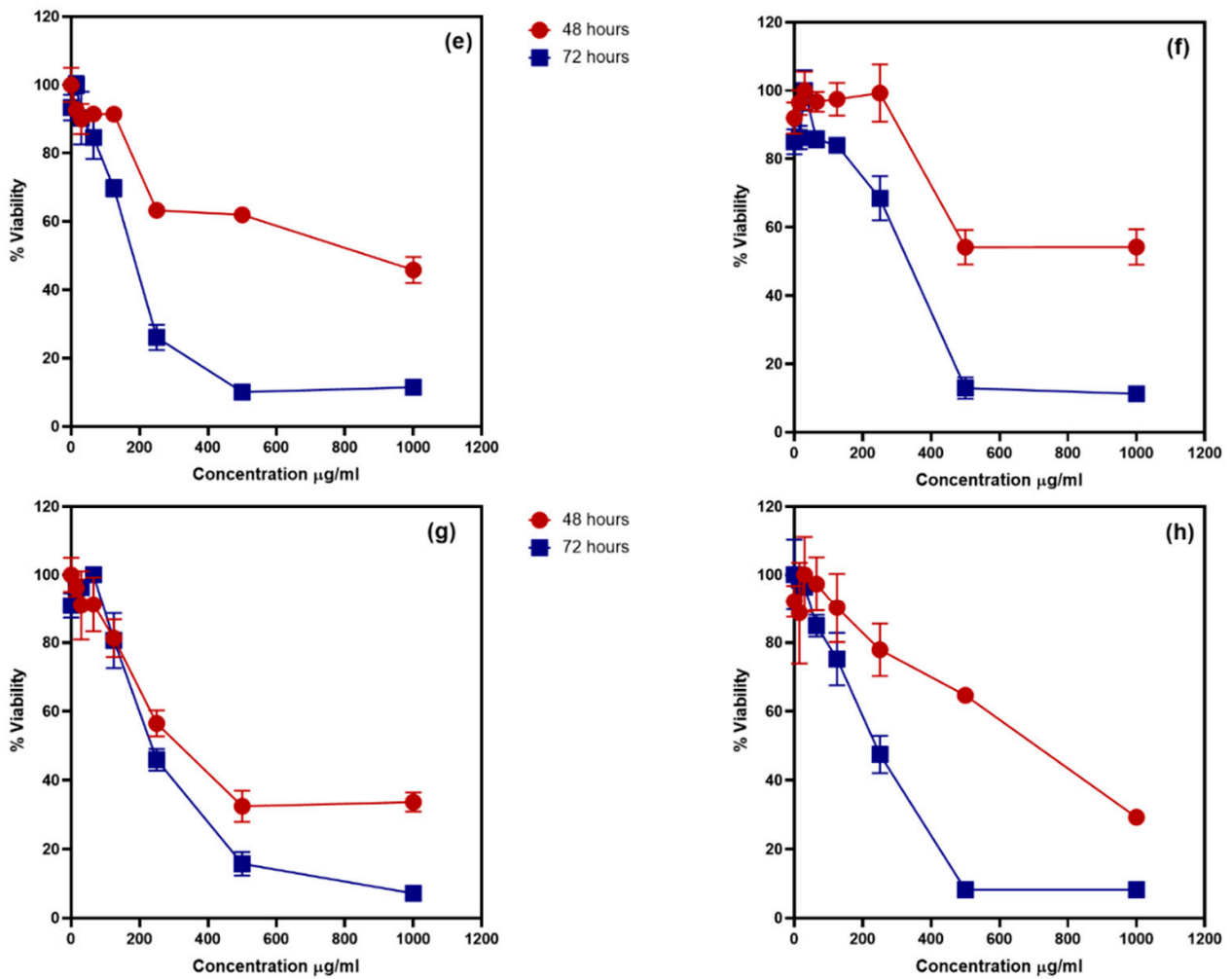

- 48 hours

72 hours

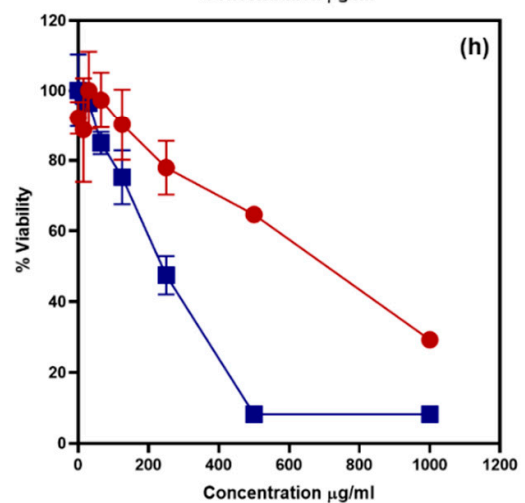

48 hours

72 hours

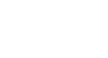

Figure 1. Graphical representation of cell viability percentage with $M$. peregrina tuber extracts on MCF-7 and Caco-2 cells with 48 and 72 h incubation: (a) - Hexane extract in MCF-7; (b) - hexane extract in Caco-2 (c) —chloroform extract in MCF-7; (d)—chloroform extract in Caco-2; (e)—acetone extract in MCF-7; (f) — acetone extract in Caco-2 (g) — methanol extract in MCF-7 and (h) - methanol extract in Caco-2. Values are expressed as mean \pm SD of three experiments ( $p$-value relative to control group: $p<0.05)$. 

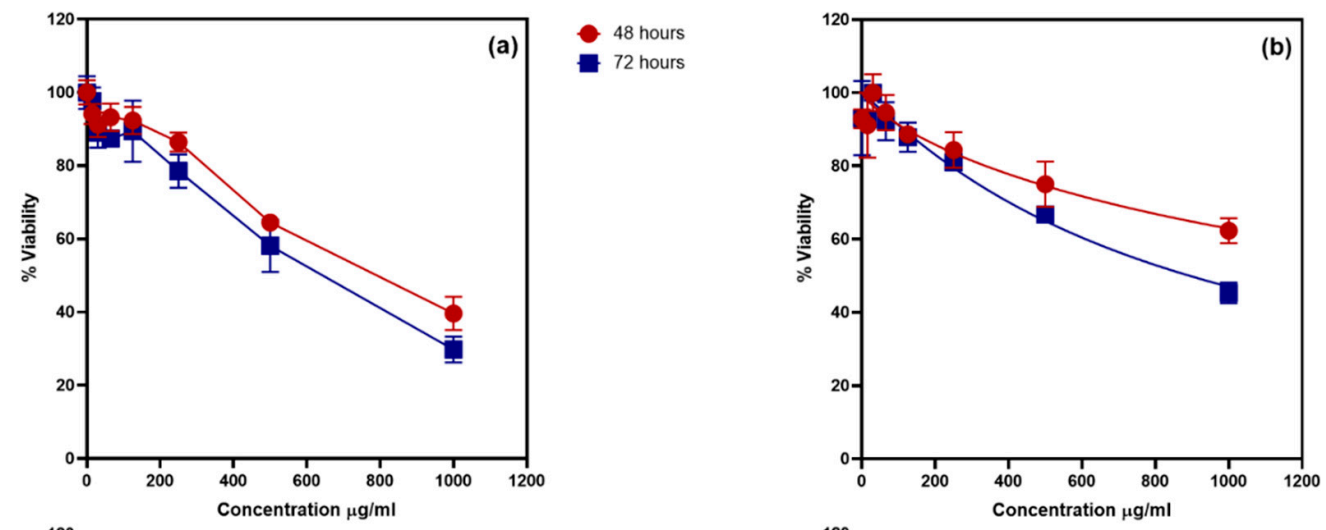

- 48 hours

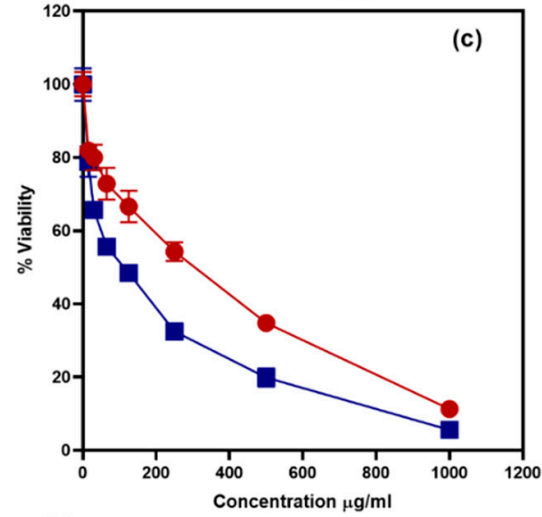

48 hours
72 hours
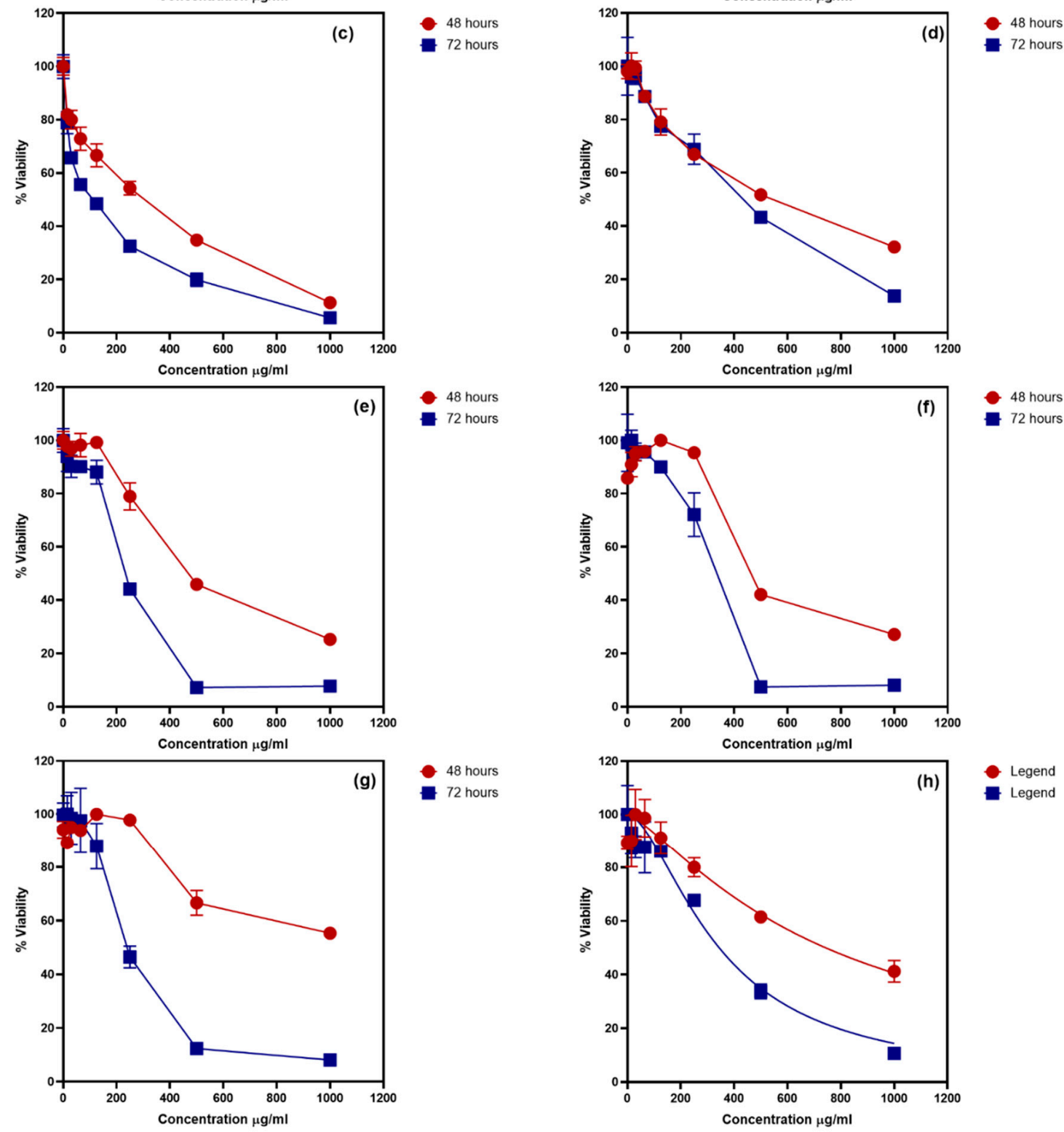

Figure 2. Graphical representation of cell viability percentage with $M$. peregrina leaves extracts on MCF-7 and Caco-2 cells with 48 and $72 \mathrm{~h}$ incubation: (a) - Hexane extract in MCF-7; (b) - hexane extract in Caco-2; (c)—chloroform extract in MCF-7; (d)—chloroform extract in Caco-2; (e)—acetone extract in MCF-7; (f) — acetone extract in Caco-2; (g) - methanol extract in MCF-7 and (h) - methanol extract in Caco-2. Values are expressed as mean $\pm \mathrm{SD}$ of three experiments ( $p$-value relative to control group: $p<0.05$ ). 


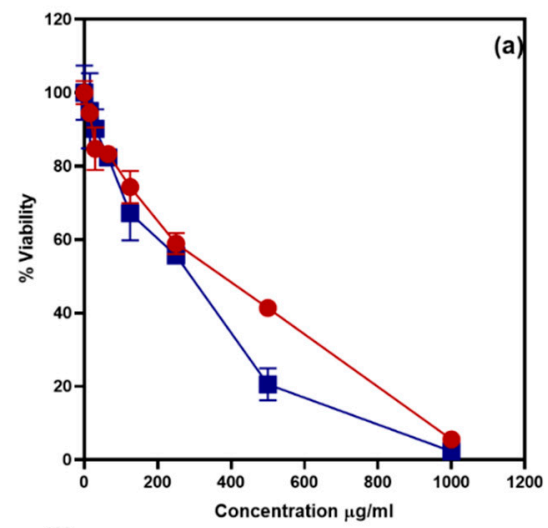

48 hours

72 hours

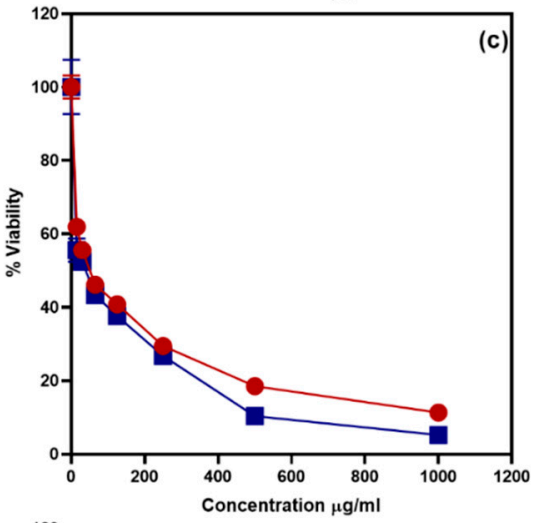

- 48 hours

72 hours

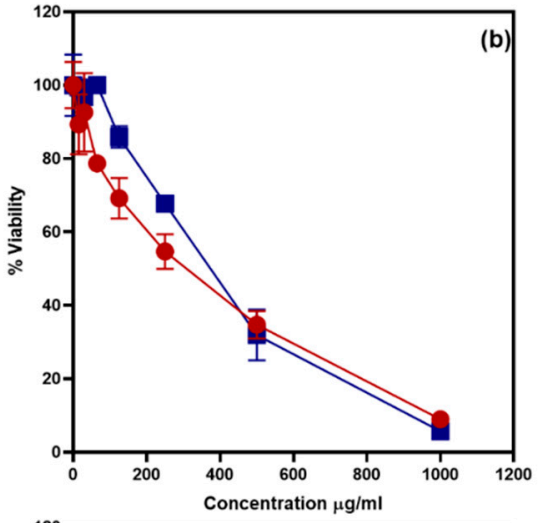

- 48 hours

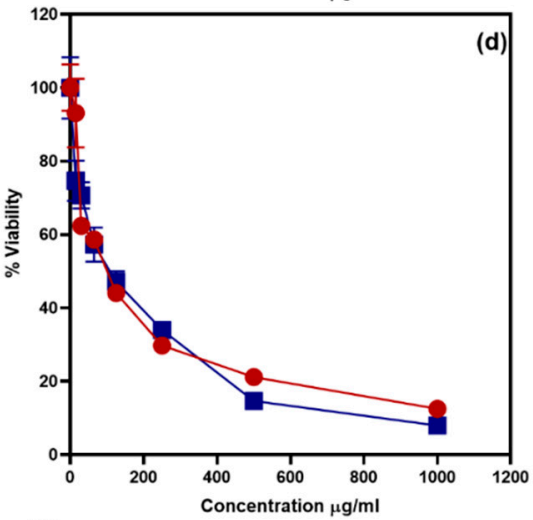

- 48 hours

72 hours

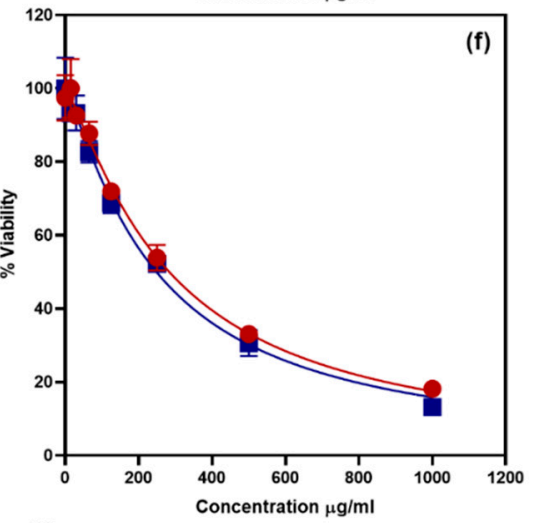

48 hours

72 hours



- 48 hours

72 hours
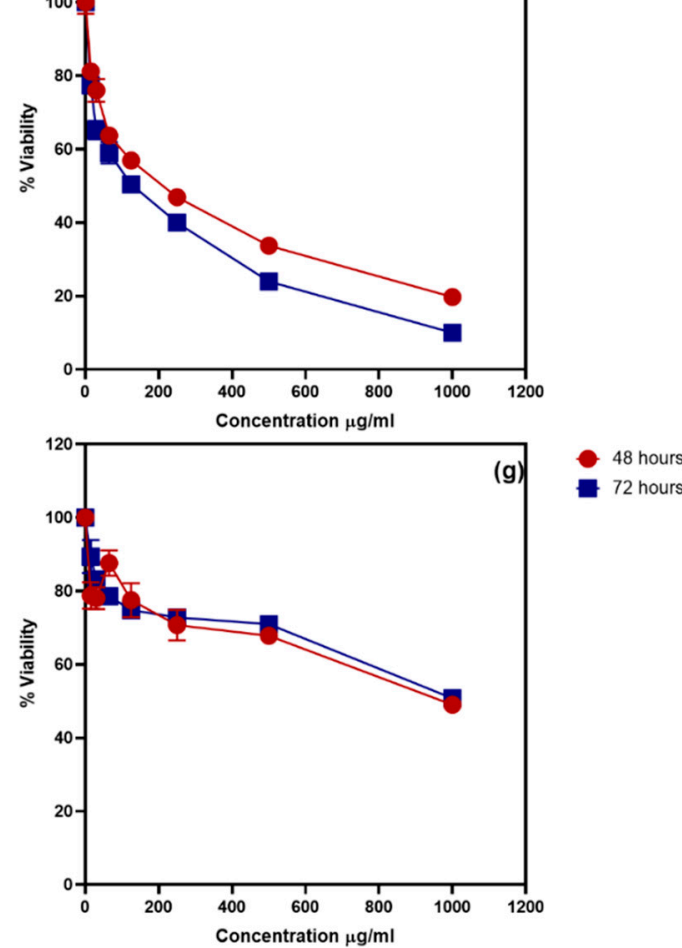

- 48 hours

72 hours

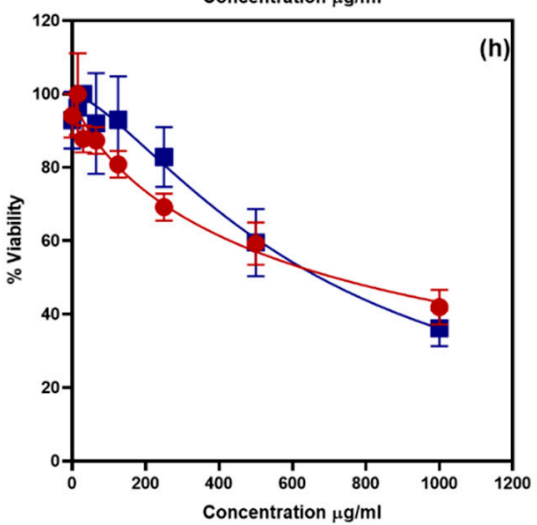

- 48 hours

72 hours

Figure 3. Graphical representation of cell viability percentage with $M$. peregrina stem extracts on MCF-7 and Caco-2 cells with 48 and $72 \mathrm{~h}$ incubation: (a) - Hexane extract in MCF-7; (b) - hexane extract in Caco-2; (c)—chloroform extract in MCF-7; (d)—chloroform extract in Caco-2; (e)—acetone extract in MCF-7; (f) - acetone extract in Caco-2; (g) - methanol extract in MCF-7 and (h) - methanol extract in Caco-2. Values are expressed as mean $\pm \mathrm{SD}$ of three experiments ( $p$-value relative to control group: $p<0.05)$ 
Table 2. Cytotoxic activity of different solvent extracts of tuber, leaves and stem of M. Peregrina on MCF-7 and Caco-2 cancer cell lines.

\begin{tabular}{|c|c|c|c|c|c|}
\hline \multirow{3}{*}{ Plant Parts } & \multirow{3}{*}{ Name of the Extract } & \multicolumn{4}{|c|}{$\mathrm{IC}_{50}(\mu \mathrm{g} / \mathrm{mL})$} \\
\hline & & \multicolumn{2}{|c|}{ MCF-7 } & \multicolumn{2}{|c|}{ Caco-2 } \\
\hline & & $48 \mathrm{~h}$ & $72 \mathrm{~h}$ & $48 \mathrm{~h}$ & $72 \mathrm{~h}$ \\
\hline \multirow{4}{*}{ Tubers } & Hexane & 188.6 & 164.3 & 367.4 & 256.5 \\
\hline & Chloroform & 426.4 & 326.5 & 1076 & 734.6 \\
\hline & Acetone & 807.8 & 167.4 & 924.6 & 295 \\
\hline & Methanol & 360.8 & 237.6 & 630.9 & 214.1 \\
\hline \multirow{4}{*}{ Leaves } & Hexane & 766.7 & 592.5 & 1950 & 894.2 \\
\hline & Chloroform & 220 & 86.58 & 500.9 & 72.9 \\
\hline & Acetone & 501.1 & 230.4 & 525.2 & 304.4 \\
\hline & Methanol & 1068 & 242.8 & 743.1 & 344.3 \\
\hline \multirow{4}{*}{ Stem } & Hexane & 291.2 & 221.8 & 251.4 & 342.6 \\
\hline & Chloroform & 45.53 & 33.32 & 93.75 & 87.76 \\
\hline & Acetone & 171.5 & 101.7 & 283.5 & 248.5 \\
\hline & Methanol & 1993 & 1912 & 714.5 & 673.5 \\
\hline
\end{tabular}


Figure 4. Graphical representation of cell viability percentage of doxorubicin (a)—on MCF-7 for $48 \mathrm{~h}$ incubation; (b) —on MCF-7 for $72 \mathrm{~h}$ incubation; (c)—on Caco-2 for $48 \mathrm{~h}$ incubation; (d) —on MCF-7 for $72 \mathrm{~h}$ incubation. Values are expressed as mean $\pm \mathrm{SD}$ of three experiments ( $p$-value relative to control group: $p<0.05)$.

In the previous study with Moringa species, which showed a variation of cell viability with type of solvents used in the extraction method, the $\mathrm{IC}_{50}$ of dichloromethane extract varied from 112 to $133 \mu \mathrm{g} / \mathrm{mL}$ for HepG2, Caco-2 and MCF-7 cancer cells, whereas it increases to more than $250 \mu \mathrm{g} / \mathrm{mL}$ with methanol extract [47]. The result of the present study is also similar to the previous study made by Cassiem and de Kock [48] on apricot and peach kernel on human colon cancer cells in vitro. In that report [48], $100 \mu \mathrm{g} / \mathrm{mL}$ concentration of hydrophilic extract of Chinese apricot and $1000 \mu \mathrm{g} / \mathrm{mL}$ concentration of lipophilic and hydrophilic extract of Chinese apricot stimulated the growth of colon 
cancer cells (HT-29) after $72 \mathrm{~h}$ of incubation. Whereas 100 and $1000 \mu \mathrm{g} / \mathrm{mL}$ concentrations of South African apricot extract inhibit the proliferation of HT-29 cells, while the intermediate concentration $(500 \mu \mathrm{g} / \mathrm{mL})$ of South African apricot extract stimulated the cell proliferation. This may be possibly related to the biphasic nature of the phytoconstituent present in the extracts. In the present investigation, the chloroform extracts of leaves and stem showed remarkable anti-proliferative and apoptotic effect on MCF-7 cell lines. At the concentration of $500 \mu \mathrm{g} / \mathrm{mL}$ in chloroform extract (72 $\mathrm{h}$ incubation), the extract inhibited 95\% cell growth in MCF-7 cells. In contrast, the same extract required $800 \mu \mathrm{g} / \mathrm{mL}$ to perform the same activity in Caco- 2 cell line after $72 \mathrm{~h}$ incubation. These results are in accordance with the study made by Elsayed et al. [49] on cytotoxicity of Moringa oleifera essential oil against MCF-7, HeLa, HepG2, Caco-2 and L929 cancer cell lines. The essential oil showed varied $\mathrm{IC}_{50}$ values $(\mathrm{MCF}-7=226.1 \mu \mathrm{g} / \mathrm{mL}, \mathrm{HeLa}=442.8 \mu \mathrm{g} / \mathrm{mL}$, HepG2 $=751.9 \mu \mathrm{g} / \mathrm{mL}$, Caco-2 $\geq 1000 \mu \mathrm{g} / \mathrm{mL}$ and $\mathrm{L} 929 \geq 1000 \mu \mathrm{g} / \mathrm{mL}$ ) against the studied cell lines at the same concentrations.

Various extracts of Polygonum tinctorium were studied for cytotoxic activity on different types of human cancer cell lines. The results on the cytotoxic activity of P. tinctorium were diverse depending on the extracts and cancer types [50]. Hence, the anti-proliferation effect is purely depending on the plant part and type of cancer cells taken for the study. The raw extract Scutellaria baicalensis dried root showed anti-proliferative effect with the $\mathrm{IC}_{50}$ value of $0.9 \mathrm{mg} / \mathrm{mL}$ against MCF-7 [51]. Moreover, some of the other Moringa extracts that exhibited less than $200 \mu \mathrm{g} / \mathrm{mL} \mathrm{IC}_{50}$ values include hexane $(164.3 \mu \mathrm{g} / \mathrm{mL}$ and $167.4 \mu \mathrm{g} / \mathrm{mL})$ and acetone extracts of tuber $(167.4 \mu \mathrm{g} / \mathrm{mL})$ and stem $(101.7 \mu \mathrm{g} / \mathrm{mL})$ on MCF-7 at $72 \mathrm{~h}$ incubation, The anti-proliferative and apoptotic effect of other $M$. peregrina extracts on MCF-7 (72 $\mathrm{h}$ incubation) were in the order of hexane extract of stem $\left(\mathrm{IC}_{50}=221.8 \mu \mathrm{g} / \mathrm{mL}\right)>$ acetone extract of leaves $\left(\mathrm{IC}_{50}=230.4 \mu \mathrm{g} / \mathrm{mL}\right)>$ methanol extract of tuber $\left(\mathrm{IC}_{50}=237.6 \mu \mathrm{g} / \mathrm{mL}\right)>$ methanol extract of leaves $\left(\mathrm{IC}_{50}=242.8 \mu \mathrm{g} / \mathrm{mL}\right)>$ chloroform extract of tubers $\left(\mathrm{IC}_{50}=326.5 \mu \mathrm{g} / \mathrm{mL}\right)>$ hexane extract of leaves $\left(\mathrm{IC}_{50}=592.5 \mu \mathrm{g} / \mathrm{mL}\right)$ $>$ methanol extract of stem $\left(\mathrm{IC}_{50}=1912 \mu \mathrm{g} / \mathrm{mL}\right)$. Comparatively higher concentration is required for the Caco-2 cell lines to get the same effect of MCF-7 with Moringa extracts. This resistance in activity of Caco- 2 cell lines is reported in the previous reports with the anti-cancer activity Moringa oil, which showed five times more concentration required for the 50\% cell death in Caco-2 cells than MCF-7 [52]. In our result, only chloroform extracts of leaves showed slightly lesser concentration required for the $\mathrm{IC}_{50}$ values on Caco- 2 cells. Besides, anti-proliferative/apoptotic effect studied for the extracts on Caco-2 cell lines were in the order of methanol extract of tuber $\left(\mathrm{IC}_{50}=214.1 \mu \mathrm{g} / \mathrm{mL}\right)>$ acetone extract of stem $\left(\mathrm{IC}_{50}=248.5 \mu \mathrm{g} / \mathrm{mL}\right)>$ hexane extract of tubers $\left(\mathrm{IC}_{50}=256.5 \mu \mathrm{g} / \mathrm{mL}\right)>$ acetone extract of tubers $\left(\mathrm{IC}_{50}=295 \mu \mathrm{g} / \mathrm{mL}\right)>$ acetone extracts of leaves $\left(\mathrm{IC}_{50}=304.4 \mu \mathrm{g} / \mathrm{mL}\right)>$ hexane extract of stem $\left(\mathrm{IC}_{50}=342.6 \mu \mathrm{g} / \mathrm{mL}\right)>$ methanol extract of leaves $\left(\mathrm{IC}_{50}=344.3 \mu \mathrm{g} / \mathrm{mL}\right)>$ methanol extract of stem $\left(\mathrm{IC}_{50}=673.5 \mu \mathrm{g} / \mathrm{mL}>\right.$ chloroform extract of tubers $\left(\mathrm{IC}_{50}=734.6 \mu \mathrm{g} / \mathrm{mL}\right)>$ hexane extract of leaves $\left(\mathrm{IC}_{50}=894.2 \mu \mathrm{g} / \mathrm{mL}\right)$. United States National Cancer Institute (US-NCI) explains that crude plant extracts that have an $\mathrm{IC}_{50}$ value of less than $100 \mu \mathrm{g} / \mathrm{mL}$ can be considered as active ones and $\mathrm{IC}_{50}$ values less than $30 \mu \mathrm{g} / \mathrm{mL}$ can be used for further isolation of the active molecule [53]. In the current research, some of the extracts also align with a similar range to the $\mathrm{IC}_{50}$ recommendation from the US-NCI. IC 50 values clearly revealed that the methanol, acetone and hexane extracts on the two cell lines have less cytotoxicity. Interestingly, the chloroform extract has excellent cytotoxic activity for both types of cancer cells. In particular, the stem extract on the MCF-7 cell lines has an $\mathrm{IC}_{50}$ of $33.33 \mu \mathrm{g} / \mathrm{mL}$, which can be considered a more active one as per the National Cancer Institute.

In this study, the cytotoxicity of $M$. peregrina extract on the healthy cell line 3T3-L1 fibroblast cells was also investigated to compare the impact on cancer cells (MCF-7 and Caco-2). The effect of the extract on healthy cells 3T3L1 was milder (Figure 5) compared to the effect of the extract on cancer cells after $72 \mathrm{~h}$ incubation. The most potent extract observed in the study, chloroform extract of leaves and stem, required less than $100 \mu \mathrm{g} / \mathrm{mL}$ 
to observe $50 \%$ cell death at $72 \mathrm{~h}$ of incubation, but in the 3T3L1 cell required $<300 \mu \mathrm{g} / \mathrm{mL}$. It indicates the anti-cancerous property of the $M$. peregrina extract and shows that it can destroy the cancer cells at a certain level.
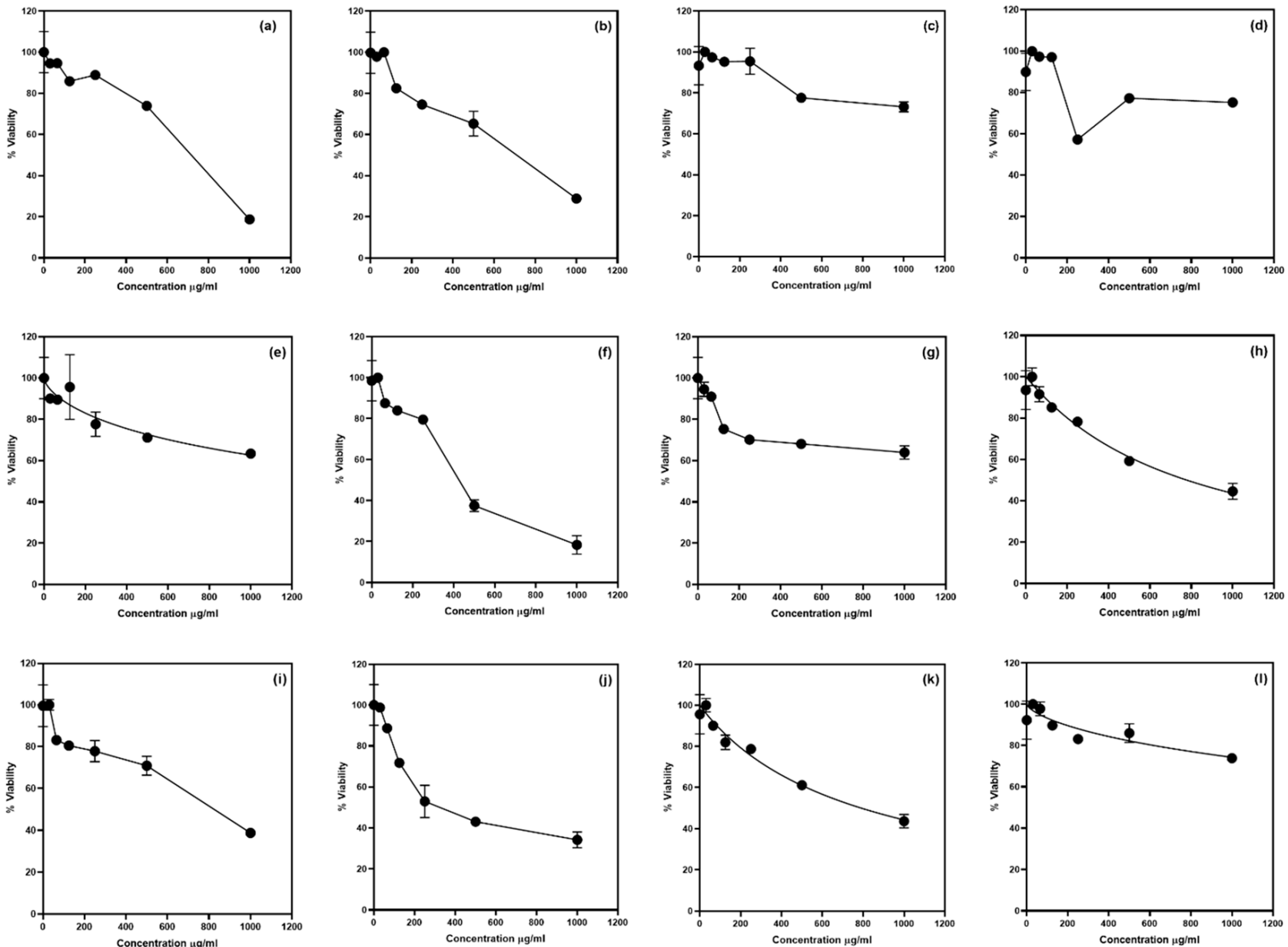

Figure 5. Graphical representation of cell viability percentage of different $M$. peregrina extracts on 3T3L1 with 72 h incubation: (a)—Hexane extract (Tubers); (b)—chloroform extract (tubers); (c)—acetone extract (tubers); (d) — methanol extract (tubers); (e)—hexane extract (leaves); (f)—chloroform extract (leaves); (g)—acetone extract (leaves); (h)—methanol extract (leaves); (i)—hexane extract (stem); (j)—chloroform extract (stem); (k)—acetone extract (stem); (1)—methanol extract (stem). Values were expressed as mean $\pm \mathrm{SD}$ of three experiments ( $p$-value relative to control group: $p<0.05$ ).

To confirm the mode of activity of the extract underlying the anti-cancer property, DNA fragmentation and PARP cleavage assay were performed. The DNA fragmentation assay result showed the fragmentation of the DNA in all the extracts in both cell lines, but clear separation of each fragment cannot be visualized properly. The DNA fragmentation assays performed on the Caco-2 cells and MCF-7 cells are shown in Figure 6. Fragmentation of the DNA was observed in all the samples without showing adequate bands. Therefore, the DNA fragmentation result is not enough to confirm the apoptosis in both cell lines. 

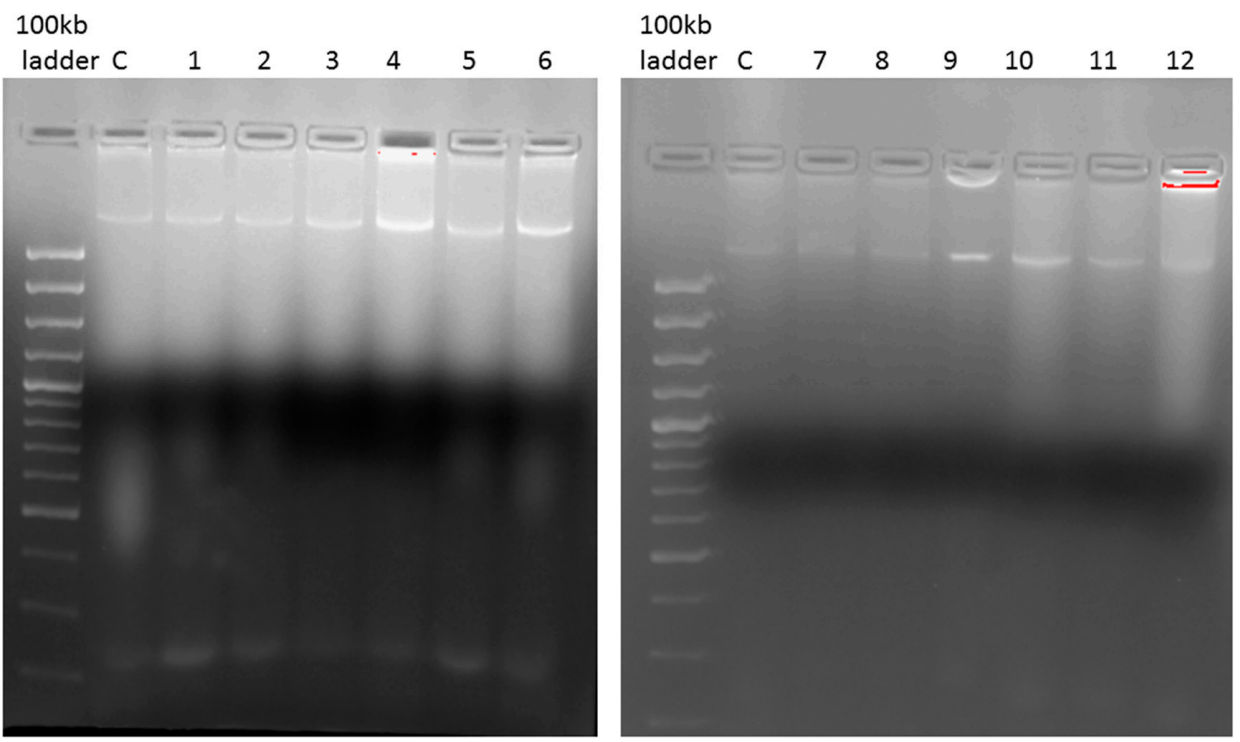

(A)


(B)

Figure 6. DNA fragmentation assay of the extracts of M. peregrina. (A) Treatment on Caco-2 cells, (B) treatment on MCF-7 cells. Lanes: C—control, ' 1 ' — hexane extract (tubers); '2' —chloroform extract (tubers); '3'-acetone extract (tubers); '4'-methanol extract (tubers); ' 5 ' - hexane extract (leaves); '6'—chloroform extract (leaves); '7'-acetone extract (leaves); ' 8 '—methanol extract (leaves); '9' hexane extract (stem); '10'—chloroform extract (stem); '11'—acetone extract (stem); '12' —Methanol extract (stem).

Caspase 3 and cleavage of PARP protein are the hallmarks of apoptosis in cancer cells. In our studies we observed the PARP cleavage was found in all the cell lines irrespective of the cancer cell lines. In Figures 7 and 8, PARP cleavage intensity of extracts is expressed in the Caco-2 and MCF-7 cell lines, respectively. PARP cleavage increased based on the concentration increases as well as the cell viability decreases. However, there was no concrete fragmentation observed in the DNA fragmentation assay; therefore, the cause of cell death was not able to be confirmed as apoptosis; it may be either apoptosis, necrosis or proptosis. Recent studies indicate that caspase 3 activation and PARP cleavage were also observed in necrosis and proptosis [54,55]. 


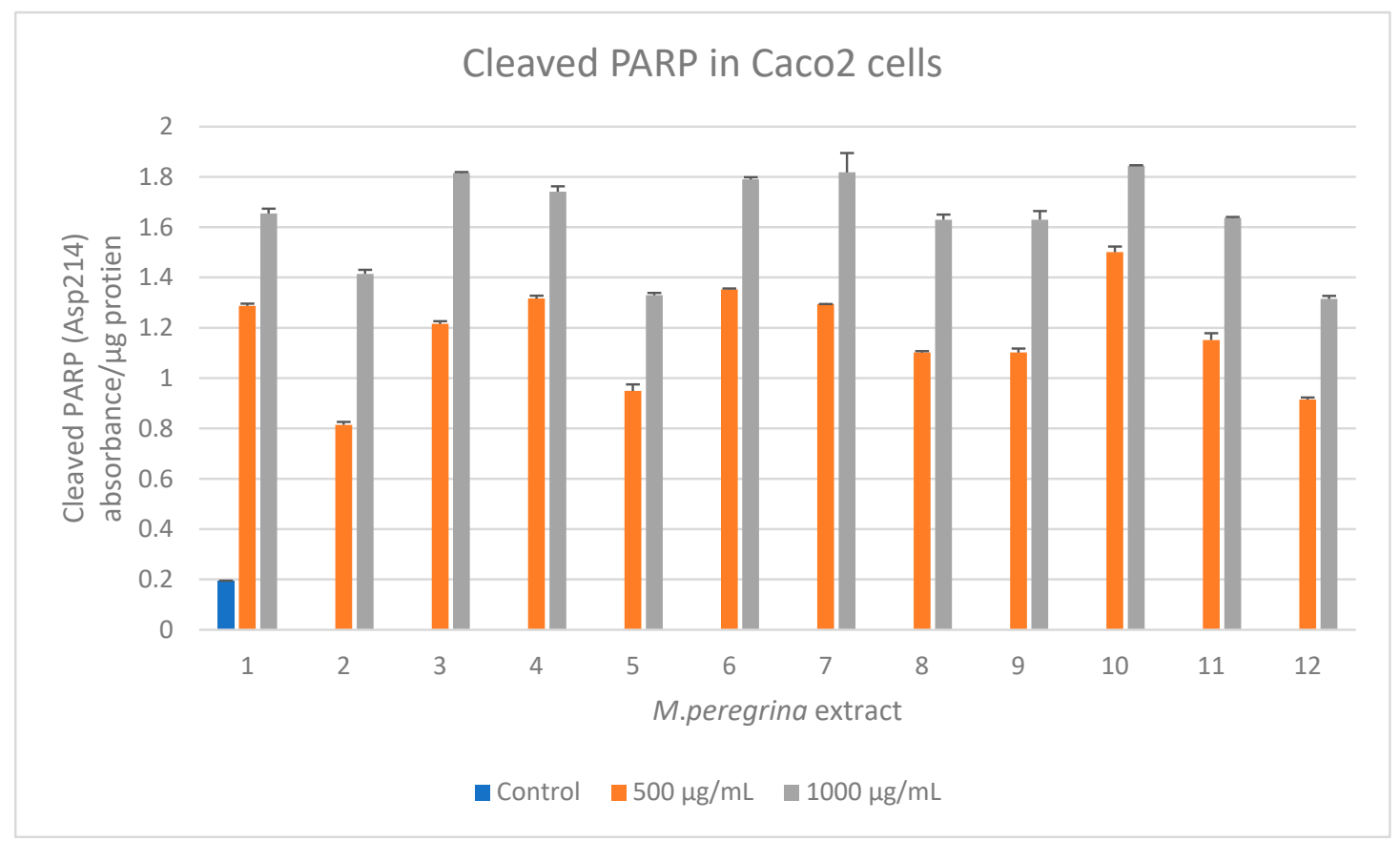

Figure 7. Graphical representation of cleaved PARP in the different M. peregrina extracts on Caco-2 with $72 \mathrm{~h}$ incubation: ' 1 '-Hexane extract (tubers); ' 2 '- chloroform extract (tubers); ' 3 '- acetone extract (tubers); ' 4 '-methanol extract (tubers); ' 5 '- -hexane extract (leaves); ' 6 ' — chloroform extract (leaves); '7'-acetone extract (leaves); ' 8 '-methanol extract (leaves); ' 9 ''10'-Chloroform extract (stem); '11'-Acetone extract (stem); '12'-Methanol extract (stem). One way ANOVA analysis to compare between control, 500 and $1000 \mu \mathrm{g} / \mathrm{mL}$ of the extract $(p<0.005)$.

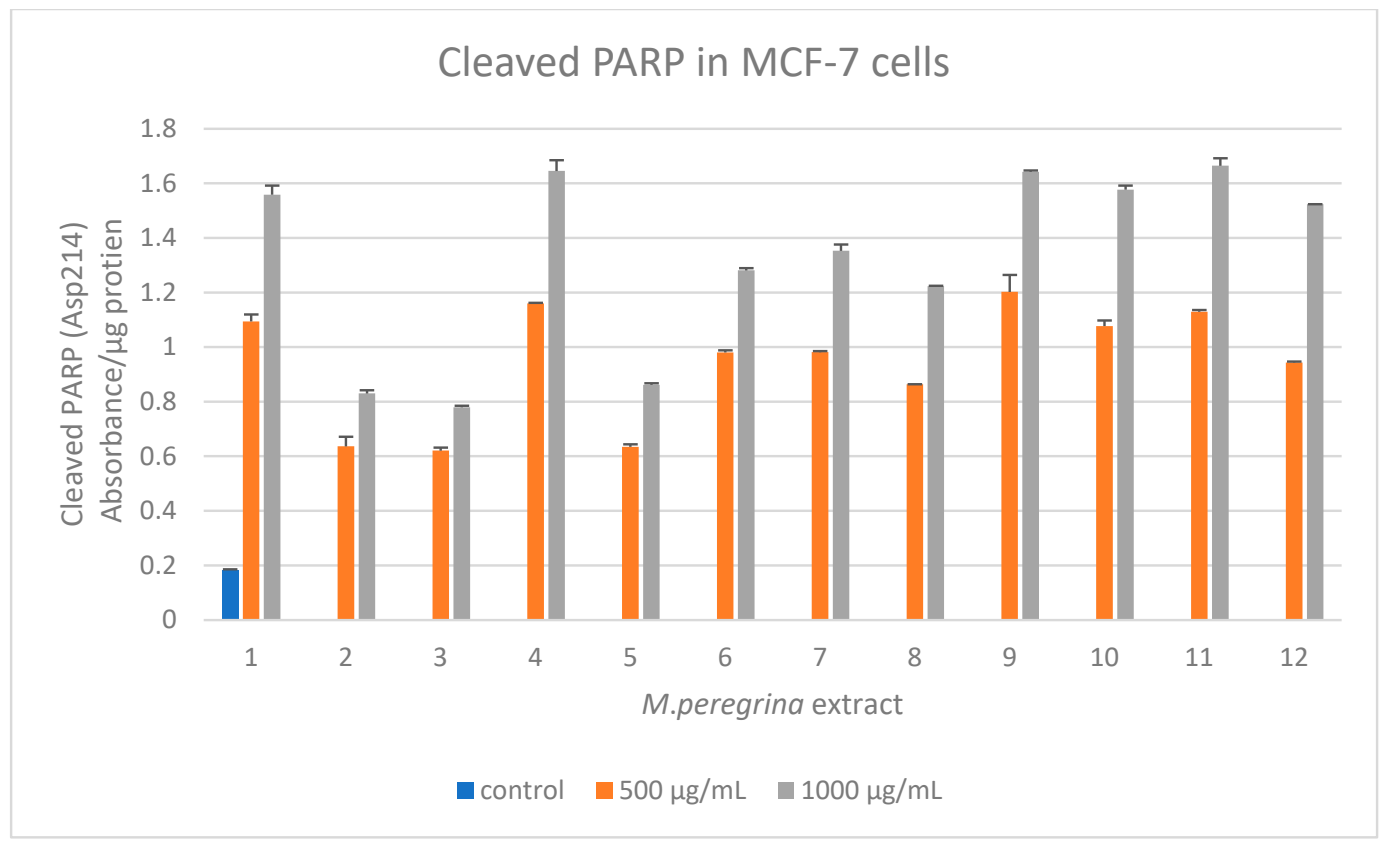

Figure 8. Graphical representation of cell viability percentage of different $M$. peregrina extracts on Caco-2 with $72 \mathrm{~h}$ incubation: ' 1 ' - Hexane extract (tubers); ' 2 ' — chloroform extract (tubers); ' 3 ' - acetone extract (tubers); ' 4 '-methanol extract (tubers); ' 5 '- hexane extract (leaves); ' 6 ' — chloroform extract (leaves); '7'-acetone extract (leaves); ' 8 ' - methanol extract (leaves); '9' - hexane extract (stem); '10' — chloroform extract (stem); '11'—acetone extract (stem); '12'—methanol extract (stem). One way ANOVA analysis to compare between control, $500 \mu \mathrm{g} / \mathrm{mL}$ and $1000 \mu \mathrm{g} / \mathrm{mL}$ of the extract $(p<0.005)$. 
Chloroform extract of the stem may contain multiple small active compounds that enhance synergistic actions by targeting protein molecules involved in the breast and colon cancer progression pathways; improve the pharmacokinetics property of the molecules in the extract, by targeting the enzymes and transporters involved in the cancer metabolism of drug resistance; and also can eliminate the toxicity to improve pharmacological efficacy of chemotherapeutic drugs.

From this current work, it can be concluded that $M$. peregrina possessed strong anticancerous activity against breast cancer cell and colon cancer cells, which might be due to the presence of promising anti-cancer compounds in the tuber, leaves and stem of the plant. Thus, it is clear that non-polar solvent chloroform is able to dissolve the active compounds from the source to the extract of M. peregrina, and it showed maximum anti-cancer properties compared to other extracts. In vivo pharmacological and toxicological studies are required to prove the unexplored beneficial aspects of this medicinal plant. Further studies are required on the isolation and characterization of anticancer molecules from the tubers and stem of the M. peregrina plant, which is underway in the laboratory. Moreover, the percentage combination of the molecules in the extract is also under investigation.

Author Contributions: Conceptualization, A.J.; Formal analysis, S.K.S.A.K., A.S., J.K.; Funding acquisition, A.J.; Investigation, S.K.S.A.K., A.S., J.K.; Methodology, A.S., J.K.; Project administration, A.J.; Supervision, A.J., A.S.A.D., M.A.M.A.; Validation, A.S.A.D., M.A.M.A., S.S.K., A.J.; Writingoriginal draft, S.K.S.A.K., A.S.; Writing—review and editing, A.S.A.D., M.A.M.A., S.S.K., A.J. All authors have read and agreed to the published version of the manuscript.

Funding: This research was funded by UAEU, UPAR\#31F092.

Institutional Review Board Statement: Not applicable.

Informed Consent Statement: Not applicable.

Data Availability Statement: Not applicable.

Acknowledgments: The authors would like to thank the support from MS Horticulture Program. The assistance from staff of Al Foah Experimental Station and E3, F1 labs, CAVM, UAEU is greatly acknowledged.

Conflicts of Interest: The authors declare no conflict of interest.

\section{References}

1. Bray, F.; Ferlay, J.; Soerjomataram, I.; Siegel, R.L.; Torre, L.A.; Jemal, A. Global cancer statistics 2018: Globocan estimates of incidence and mortality worldwide for 36 cancers in 185 countries. CA Cancer J. Clin. 2018, 68, 394-424. [CrossRef] [PubMed]

2. WHO. Global cancer data. In International Agency for Research on Cancer World Health Organization; WHO: Geneva, Switzerland, 2018; p. 263.

3. Mentella, M.C.; Scaldaferri, F.; Ricci, C.; Gasbarrini, A.; Miggiano, G.A.D. Cancer and Mediterranean diet: A review. Nutrients 2019, 11, 2059. [CrossRef] [PubMed]

4. $\quad$ Pinto da Silva, L.; Magalhães, C.M.; Núñez-Montenegro, A.; Ferreira, P.J.; Duarte, D.; Rodríguez-Borges, J.E.; Vale, N.; Esteves da Silva, J.C. Study of the combination of self-activating photodynamic therapy and chemotherapy for cancer treatment. Biomolecules 2019, 9, 384. [CrossRef] [PubMed]

5. Singh, S.; Sharma, B.; Kanwar, S.S.; Kumar, A. Lead phytochemicals for anticancer drug development. Front. Plant Sci. 2016, 7, 1667. [CrossRef]

6. Adnan, M.; Siddiqui, A.J.; Hamadou, W.S.; Snoussi, M.; Badraoui, R.; Ashraf, S.A.; Jamal, A.; Awadelkareem, A.M.; Sachidanandan, M.; Hadi, S.; et al. Deciphering the Molecular Mechanism Responsible for Efficiently Inhibiting Metastasis of Human Non-Small Cell Lung and Colorectal Cancer Cells Targeting the Matrix Metalloproteinases by Selaginella repanda. Plants 2021, 10, 979. [CrossRef]

7. Tewari, D.; Rawat, P.; Singh, P.K. Adverse drug reactions of anticancer drugs derived from natural sources. Food Chem. Toxicol. 2019, 123, 522-535. [CrossRef]

8. Taylor, P.G.; Cesari, I.M.; Arsenak, M.; Ballen, D.; Abad, M.J.; Fernández, A.; Milano, B.; Ruiz, M.-C.; Williams, B.; Michelangeli, F. Evaluation of Venezuelan medicinal plant extracts for antitumor and antiprotease activities. Pharm. Biol. 2006, 44, 349-362. [CrossRef]

9. Yaglioglu, A.S.; Eser, F. Screening of some Juniperus extracts for the phenolic compounds and their antiproliferative activities. S. Afr. J. Bot. 2017, 113, 29-33. [CrossRef] 
10. Xia, J.; Yang, C.; Wang, Y.; Yang, Y.; Yu, J. Antioxidant and antiproliferative activities of the leaf extracts from Trapa bispinosa and active components. S. Afr. J. Bot. 2017, 113, 377-381. [CrossRef]

11. Almoulah, N.F.; Voynikov, Y.; Gevrenova, R.; Schohn, H.; Tzanova, T.; Yagi, S.; Thomas, J.; Mignard, B.; Ahmed, A.A.A.; El Siddig, M.A.; et al. Antibacterial, antiproliferative and antioxidant activity of leaf extracts of selected Solanaceae species. S. Afr. J. Bot. 2017, 112, 368-374. [CrossRef]

12. Zhu, H.; Lv, G.; Qu, Q.; Xu, J.; Zhang, L.; Zhu, Y. Thunder god vine extract exerts antiproliferative effects on growth of human colon cancer cells and inhibits colon cancer growth in xenograft mice models. S. Afr. J. Bot. 2018, 115, 18-23. [CrossRef]

13. Nugraha, A.S.; Pratoko, D.K.; Damayanti, Y.D.; Lestari, N.D.; Laksono, T.A.; Addy, H.S.; Untari, L.F.; Kusumawardani, B.; Wangchuk, P. Antibacterial and anticancer activities of nine lichens of Indonesian Java Island. J. Biol. Active Prod. Nat. 2019, 9 , 39-46. [CrossRef]

14. Abdul, W.; Hajrah, N.; Sabir, J.; Al-Garni, S.; Sabir, M.; Kabli, S.; Saini, K.; Bora, R. Therapeutic role of Ricinus communis L. and its bioactive compounds in disease prevention and treatment. Asian Pac. J. Trop. Med. 2018, 11, 177. [CrossRef]

15. Adnan, M.; Siddiqui, A.J.; Hamadou, W.S.; Patel, M.; Ashraf, S.A.; Jamal, A.; Awadelkareem, A.M.; Sachidanandan, M.; Snoussi, M.; De Feo, V. Phytochemistry, Bioactivities, Pharmacokinetics and Toxicity Prediction of Selaginella repanda with Its Anticancer Potential against Human Lung, Breast and Colorectal Carcinoma Cell Lines. Molecules 2021, 26, 768. [CrossRef] [PubMed]

16. Cragg, G.M.; Pezzuto, J.M. Natural Products as a Vital Source for the Discovery of Cancer Chemotherapeutic and Chemopreventive Agents. Med. Princ. Pract. 2016, 25 (Suppl. 2), 41-59. [CrossRef] [PubMed]

17. Zunica, E.R.; Yang, S.; Coulter, A.; White, C.; Kirwan, J.P.; Gilmore, L.A. Moringa oleifera seed extract concomitantly supplemented with chemotherapy worsens tumor progression in mice with triple negative breast cancer and obesity. Nutrients 2021, 13, 2923. [CrossRef]

18. Buakaew, W.; Sranujit, R.P.; Noysang, C.; Sangouam, S.; Suphrom, N.; Thongsri, Y.; Usuwanthim, K. Evaluation of mouthwash containing Citrus hystrix DC., Moringa oleifera Lam. and Azadirachta indica A. Juss. leaf extracts on dental plaque and gingivitis. Plants 2021, 10, 1153. [CrossRef]

19. Al-Asmari, A.K.; Albalawi, S.M.; Athar, M.T.; Khan, A.Q.; Al-Shahrani, H.; Islam, M. Moringa oleifera as an anti-cancer agent against breast and colorectal cancer cell lines. PLOS ONE 2015, 10, e0135814. [CrossRef]

20. Bhadresha, K.P.; Jain, N.K.; Rawal, R.M. Assessing the protective effect of Moringa oleifera extract against bone metastasis: An in vitro simulated digestion approach. Nutr. Cancer 2021, 1-14. [CrossRef]

21. Dzuvor, C.K.; Pan, S.; Amanze, C.; Amuzu, P.; Asakiya, C.; Kubi, F. Bioactive components from Moringa oleifera seeds: Production, functionalities and applications-A critical review. Crit. Rev. Biotechnol. 2021, 1-23. [CrossRef]

22. Watanabe, S.; Okoshi, H.; Yamabe, S.; Shimada, M. Moringa oleifera Lam. in diabetes mellitus: A systematic review and meta-analysis. Molecules 2021, 26, 3513. [CrossRef]

23. Wangcharoen, W.; Gomolanee, S. Antioxidant capacity and total phenolic content of Moringa oleifera grown in Chiang Mai, Thailand. Thai J. Agri. Sci. 2011, 44, 118-124.

24. Bellostas, N.; Sørensen, J.C.; Nikiema, A.; Sørensen, H.; Pasternak, D.; Kumar, S. Glucosinolates in leaves of Moringa species grown and disseminated in Niger. Afr. J. Agric. Res. 2010, 5, 1338-1340.

25. Robiansyah, I.; Hajar, A.S.; Al-kordy, M.A.; Ramadan, A. Current status of economically important plant Moringa peregrina (Forrsk.) Fiori in Saudi Arabia: A review. Int. J. Theor. Appl. Sci. 2014, 6, 79-86.

26. Abd El-Wahab, R. Reproduction Ecology of Wild Trees and Shrubs in Southern Sinai, Egypt. Master's Thesis, Botany Department, Faculty of Science, Suez Canal University, Ismailia, Egypt, 1995.

27. Senthilkumar, A.; Karuvantevida, N.; Rastrelli, L.; Kurup, S.S.; Jaleel, A. Traditional uses, pharmacological efficacy, and phytochemistry of Moringa peregrina (Forssk.) Fiori.-A review. Front. Pharm. 2018, 9, 465. [CrossRef] [PubMed]

28. Senthilkumar, A.; Thangamani, A.; Karthishwaran, K.; Jaleel, A. Essential oil from the seeds of Moringa peregrina: Chemical composition and antioxidant potential. S. Afr. J. Bot. 2020, 129, 100-105. [CrossRef]

29. Alrayes, L.M.H.; Al Khateeb, W.M.H.; Shatnawi, M.A.M. Clonal propagation and antibacterial activity of Moringa peregrina (Forssk) fiori plant. J. Adv. Biotechnol. 2016, 6, 787-797. [CrossRef]

30. Saleh, N.M.; Mabrouk, M.I.; Salem-Bekhit, M.M.; Hafez, E.H. Challenge of Moringa peregrina Forssk as an antimicrobial agent against multi-drug-resistant Salmonella sp. Biotechnol. Biotechnol. Equip. 2017, 31, 380-386. [CrossRef]

31. Azim, S.A.A.; Abdelrahem, M.T.; Said, M.M.; Khattab, A. Protective effect of Moringa peregrina leaves extract on acetaminophen -induced liver toxicity in albino rats. Afr. J. Tradit. Complement. Altern. Med. 2017, 14, 206-216. [CrossRef] [PubMed]

32. Lalas, S.; Gortzi, O.; Athanasiadis, V.; Tsaknis, J.; Chinou, I. Determination of antimicrobial activity and resistance to oxidation of Moringa peregrina seed oil. Molecules 2012, 17, 2330-2334. [CrossRef]

33. Ghazanfar, S.A.; Al-Al-Sabahi, A.M. Medicinal plants of Northern and Central Oman (Arabia). Econ. Bot. 1993, 47, 89-98 [CrossRef]

34. Nawash, O.S.; Ahmad Al-S, H. The most important medicinal plants in Wadi Araba desert in South West Jordan: A review article. Adv. Env. Biol. 2011, 418-426.

35. Al-Khatani, H. Moringa peregrina (Al-yassar of Al-ban) seeds oil from northwest Saudi Arabia. J. King Saud Univ. Agri. Sci. 1995, 7 , 31-45.

36. Elbatran, S.A.; Abdel-Salam, O.M.; Abdelshfeek, K.A.; Nazif, N.M.; Ismail, S.I.; Hammouda, F.M. Phytochemical and pharmacological investigations on Moringa peregrina (Forssk) Fiori. Nat. Prod. Sci. 2005, 11, 199-206. 
37. Marwah, R.G.; Fatope, M.O.; Al Mahrooqi, R.; Varma, G.B.; Al Abadi, H.; Al-Burtamani, S.K.S. Antioxidant capacity of some edible and wound healing plants in Oman. Food Chem. 2007, 101, 465-470. [CrossRef]

38. El-Alfy, T.S.; Ezzat, S.M.; Hegazy, A.K.; Amer, A.M.; Kamel, G.M. Isolation of biologically active constituents from Moringa peregrina (Forssk.) Fiori. (family: Moringaceae) growing in Egypt. Pharm. Mag. 2011, 7, 109.

39. Koheil, M.A.; Hussein, M.A.; Othman, S.M.; El-Haddad, A. In-vivo antioxidant activity of Moringa peregrina against STZ-induced oxidative stress in type 2 diabetic rats. Mol. Clin. Pharmacol. 2013, 4, 65-75.

40. Tahany, M.A.; Hegazy, A.K.; Sayed, A.M.; Kabiel, H.F.; El-Alfy, T.; El-Komy, S.M. Study on combined antimicrobial activity of some biologically active constituents from wild Moringa peregrina Forssk. J. Yeast Fungal Res. 2010, 1, 15-24.

41. Elsayed, E.A.; Sharaf-Eldin, M.A.; El-Enshasy, H.A.; Wadaan, M. In vitro assessment of anticancer properties of Moringa peregrina essential seed oil on different cell lines. Pak. J. Zool. 2016, 48, 853-859.

42. Del Peso, L.; Maribel, G.G.; Carmen, P.; Román, H.; Gabriel, N. Interleukin-3-induced phosphorylation of BAD through the protein kinase Akt. Science 1997, 278, 687-689. [CrossRef]

43. Kizhakkayil, J.; Faisal, T.; Shahanas, C.; Abdulkader, H.; Mahendra, P.; Sehamuddin, G. Modulation of curcumin-induced Akt phosphorylation and apoptosis by PI3K inhibitor in MCF-7 cells. Biochem. Biophys. Res. Commun. 2010, 394, 476-481. [CrossRef]

44. Corrie, P.G. Cytotoxic chemotherapy: Clinical aspects. Medicine 2008, 36, 24-28. [CrossRef]

45. Suman, S.; Pandey, A.; Chandna, S. An improved non-enzymatic "DNA ladder assay" for more sensitive and early detection of apoptosis. Cytotechnology 2012, 64, 9-14. [CrossRef]

46. Dai, J.; Mumper, R.J. Plant phenolics: Extraction, analysis and their antioxidant and anticancer properties. Molecules 2010, 15, 7313-7352. [CrossRef]

47. Charoensin, S. Antioxidant and anticancer activities of Moringa oleifera leaves. J. Med. Plants Res. 2014, 8, 318-325.

48. Cassiem, W.; de Kock, M. The anti-proliferative effect of apricot and peach kernel extracts on human colon cancer cells in vitro. BMC Comp. Alter. Med. 2019, 19, 32. [CrossRef] [PubMed]

49. Elsayed, E.A.; Sharaf-Eldin, M.A.; Wadaan, M. In vitro evaluation of cytotoxic activities of essential oil from Moringa oleifera seeds on HeLa, $\mathrm{HepG}_{2}, \mathrm{MCF}_{-7}, \mathrm{Caco}_{2}$ and $\mathrm{L} 929$ cell lines. Asian Pac. J. Cancer Prev. 2015, 16, 4671-4675. [CrossRef]

50. Heo, B.-G.; Park, Y.-J.; Park, Y.-S.; Bae, J.-S.; Cho, J.-Y.; Park, K.; Jastrzebski, Z.; Gorinstein, S. Anticancer and antioxidant effects of extracts from different parts of indigo plant. Ind. Crop. Prod. 2014, 56, 9-16. [CrossRef]

51. Ye, F.; Xui, L.; Yi, J.; Zhang, W.; Zhang, D.Y. Anticancer activity of Scutellaria baicalensis and its potential mechanism. J. Alter. Compl. Med. 2002, 8, 567-572. [CrossRef] [PubMed]

52. Abd-Rabou, A.A.; Abdalla, A.M.; Ali, N.A.; Zoheir, K.M. Moringa oleifera root induces cancer apoptosis more effectively than leave nanocomposites and its free counterpart. Asian Pac. J. Cancer Prev. 2017, 18, 2141. [PubMed]

53. Tan, W.; Lu, J.; Huang, M.; Li, Y.; Chen, M.; Wu, G.; Gong, J.; Zhong, Z.; Xu, Z.; Dang, Y.; et al. Anti-cancer natural products isolated from Chinese medicinal herbs. Chinese Med. 2011, 6, 27. [CrossRef] [PubMed]

54. Gobeil, S.; Boucher, C.; Nadeau, D.; Poirier, G.G. Characterization of the necrotic cleavage of poly(ADP-ribose) polymerase (PARP-1): Implication of lysosomal proteases. Cell Death Differ. 2001, 8, 588-594. [CrossRef] [PubMed]

55. Liang, Y.; Yi, L.; Xue-feng, M.; Dan, H.; Yu-hui, Z.; Yong, S.; Shan-shan, S.; Tim, F.; Hai-yan, L.; Jun, F.; et al. Triclabendazole Induces Pyroptosis by Activating Caspase-3 to Cleave GSDME in Breast Cancer Cells. Front. Pharmacol. 2021, 12, 1600. [CrossRef] 